\title{
Lizboński akord
}

W dniach 14-15 lutego 2014 r. odbyło się w Lizbonie pierwsze międzynarodowe spotkanie w celu wypracowania konsensusu w temacie zatytułowanym „Rak odbytnicy - kiedy nie operować". Dyskusja nad obecną i przyszłą praktyką kliniczną miała na celu określenie nowych opcji leczenia raka odbytnicy. Wykłady dotyczyły wielu zagadnień obejmujących wpływ tzw. całkowitej odpowiedzi uzyskanej po radio-i chemioterapii na postępowanie u chorych na raka odbytnicy. Organizatorem spotkania była Fundacja Champalimaud (właściciel sieci handlowej Biedronka w Polsce). Komitetowi Naukowemu przewodniczyli Bill Heald, Geerard Beets i Carlos Carvalho. Wśród wykładowców znaleźli się przedstawiciele chirurgii, radiologii, radioterapii i patologii, m.in. Angelita Habr-Gama, Regina Beets-Tan, Gina Brown, Chris Cunningham, Jean-Pierre Gerard, Philippe Rouanet, Werner Hohenberger, Philip Quirke oraz Vincenzo Valentini.

Wyniki obrad nt. możliwości leczenia oszczędzającego, polegającego na intensywnej obserwacji (nadzór) po uzyskaniu całkowitej regresji po radio- i chemioterapii chorych na raka odbytnicy, podsumować można następująco:

\section{Potrzeba więcej dowodów naukowych}

Badania randomizowane są niewykonalne.

Współpraca międzynarodowa (rejestr) jest konieczna.

Konieczny jest dłuższy czas obserwacji chorych.

\section{Definicja całkowitej odpowiedzi klinicznej}

Całkowita: prawidłowa błona śluzowa lub blizna pokryta gładką błoną śluzową, prawie całkowita, niecałkowita.

Czas jej zdiagnozowania: 8-12 tygodni po zakończeniu radioterapii.

Nie należy pobierać biopsji (endoskopowo) w ciągu pierwszych 12 tygodni po radioterapii, gdyż jej wynik jest niemiarodajny.

Badania obrazowe: MRI (tumour regression grade) i/lub PET-CT.

\section{Strategia nadzoru}

Badanie per rectum, endoskopia, badania obrazowe

— intensywne w 1. roku obserwacji.

Opcje w odpowiedzi prawie całkowitej:

- wycięcie miejscowe przez odbyt (TEM),

- ścisły nadzór MRI lub PET-CT z badaniem per rectum i rektoskopią.

\section{Schemat leczenia w okresie „obserwacji”}

Rozważyć chemioterapię konsolidacyjną.

Brak dowodów na skuteczność chemioterapii uzupeł-

niającej (adiuwantowej):

- po resekcji/amputacji odbytnicy, poprzedzonej przedoperacyjną radio-, chemioterapią. Możliwości eskalacji dawki radioterapii:

- kontaktowa (endokawitarna), brachyterapia, EBRT, IMRT.

\section{Terminologia}

Wczesna wznowa miejscowa/wczesny odrost:

- prawdopodobnie bardziej agresywna. Późna wznowa/odrost:

- prawdopodobnie mniej agresywna.

Arbitralnie określony przedział czasu: 1 rok.

\section{Zawsze rozważyć ocenę odpowiedzi:}

Jeśli choremu zaproponowano radio-, chemioterapię, obserwacja/nadzór może być opcją postępowania, gdy zdiagnozowano całkowitą odpowiedź kliniczną (nie jest to błąd w sztuce).

Chorzy, którzy mogą odnieść największą korzyść:

- z niskimi rakami odbytnicy (w zasięgu badania palcem),

- w wieku podeszłym lub obciążeni ciężkimi chorobami współistniejącymi.

Jeśli wybrano radioterapię $5 \times 5$ Gy, można zastosować długi interwał czasowy i chemioterapię w czasie jego trwania.

\section{Współudział chorego w podejmowaniu decyzji jest konieczny po zapewnieniu pełnej i wyczerpującej informacji.}

Spodziewane są kolejne spotkania międzynarodowe na tematy związane z doskonaleniem leczenia chirurgicznego chorych na raka odbytnicy.

Prof. dr hab. n. med. Wojciech P. Polkowski

Klinika Chirurgii Onkologicznej

Uniwersytet Medyczny im. Prof. F. Skubiszewskiego w Lublinie e-mail:wojciech.polkowski@umlub.pl

Prof. dr hab. n. med. Krzysztof Bujko

Zakład Teleradioterapii

Centrum Onkologii — Instytut im. Marii Skłodowskiej-Curie w Warszawie 